\title{
SOME SUGGESTIONS FOR DEFINING AND CLASSIFYING HEARSAY
}

\section{EDMUNd M. Morgan $\dagger$}

To one who attempts to classify the almost numberless authorities dealing with the admissibility of utterances two questions present themselves at the outset: What is hearsay, and Why do Anglo-American courts refuse to receive it in evidence? Search for satisfactory answers may be facilitated by an elementary analysis of the function of a witness and of the process by which a trier uses testimony in resolving an issue of fact.

Suppose that $P$ desires to establish to the satisfaction of $T$ the proposition that $D$ committed act $\mathrm{X}$. He brings $W$ before $T$ and puts to $W$ a question. $W$ utters a series of sounds. By them he intends to express a proposition; by them he seems to $T$ to be saying: "I saw $D$ commit act X", or "I heard $D$ commit act X." From this auditory experience, $T$ makes the following inferences, each of which after the first depends upon the one preceding it: (I) That $W$ said, "I saw (or heard) $D$ commit act X"; (2) that $W$ was trying to express the proposition usually expressed by those words; (3) that $W$ then and there believed that he saw (or heard) $D$ commit act $\mathrm{X}$; and (4) that $W^{\prime}$ 's then existing belief was caused by his prior experience of seeing (or hearing) $D$ commit act $X$. As to the content of $W$ 's utterance $T$ must rely upon his own sense of hearing and his own power of translating sounds into ideas. As to the correspondence between $W^{\prime} s$ language and $D^{\prime} s$ conduct, $T$ will be dependent upon $W$ 's perception, recollection, narration and veracity, and must make a finding or assumption concerning each of these in order to reach any rational conclusion as to the truth of $P$ 's proposition. And it can make no difference to either $W$ or $T$ that $D$ 's conduct consisted of an utterance, that it was vocal rather than nonvocal or verbal rather than non-verbal. ${ }^{1}$

If $T$ is a court, $W$ will be required to make his utterance under conditions calculated to induce him to tell what he believes to be the truth, and to

$\dagger$ A. B., 1902, A. M., 1903, LL.B., I905, Harvard University ; A. M., 1919, Yale University; Professor of Law at Harvard University; author of INTRODUCTION To STUDY OF LAW (Ig24), with C. B. Whittier of CASES on Common IAw Pleading (IgI7), with J. M. Maguire of CaSES ON EvIDENCE (I934), and of numerous articles in legal periodicals on the law of Evidence.

I. All this may seem too elementary to justify statement. It is suggested, however, that had Dean Wigmore had such an analysis in mind, he would have written $\$ \$ 267$ and 271 of his treatise somewhat differently. It is possible, too, that if Professor John S. Strahorn, Jr. had taken the trouble to make articulate the steps in the series of mental operations of the trier of fact in the use of testimonial assertions, he would have felt the necessity of explaining exactly what he means by "relevant circumstantial conduct" as applied to assertive utterances in his interesting article, $A$ Reconsideration of the Hearsay Rule and Admissions (I937) 85 U. OF PA. L. REv. 484, 49I, 564 . 
enable $T$ to put a fair value upon it. $W$ will have to speak under oath, subject to a penalty for perjury, usually at a public hearing in the presence of $T$. If the court is a common law court, he will also be subject to confrontation and cross-examination by the party against whom his utterance is offered. Knowledge of this will be an additional stimulus to his desire to tell the truth; and cross-examination in $T$ 's presence, if intelligently exercised, will furnish $T$ a solid basis for valuing $W^{\prime} s$ testimony. If $W$ refuses to submit to any of these conditions, he will not be heard.

Now assume that $W$ ' $s$ language, as interpreted by $T$, is " $B$ told me that he saw (or heard) $D$ commit act X." Here again $W$ intends to express a proposition concerning his own personal experience with $B$; here again $T$ will go through the same series of mental processes to determine whether $W$ actually had that experience; but when $T$ has concluded that $B$ did utter the words reported by $W, T$ has done no more than find that $B$ in $W^{\prime} s$ presence expressed a proposition concerning a personal experience of $B . \quad B$ is not now under oath or subject to a penalty for perjury or speaking publicly in the presence of $T$. Neither is he now confronted or subject to crosseramination by the party against whom his utterance is offered. Furthermore none of these stimuli or safeguards was present at the time $B$ spoke. Yet $P$ is asking $T$ to rely upon $B$ 's perception, recollection, narration and veracity; and if $T$ is to make a finding regarding $D$ 's conduct, $T$ must treat $B$ in all respects as in the former case $T$ treated $W$. In short, upon the issue of $B^{\prime} s$ conduct, $\mathrm{P}$ is presenting $W$ as the witness, but upon the issue of $D$ 's conduct, he is offering $B$ as the witness. In this instance $B$ is performing all the functions which $W$ performed in the prior case.

$W$ would not have been heard in this case as to $B^{\prime} s$ conduct or in the prior case as to $D$ 's conduct unless he had submitted to the prescribed conditions designed to stimulate honesty of utterance by him and to make possible intelligent evaluation of his testimony by $T$. It would seem to follow that $P$ cannot be permitted to avoid the imposition of these conditions upon $B$ by the device of transmitting $B$ 's testimony through $W$. Analytically $B$ 's utterance is hearsay, and its reception would render nugatory most of the regulations prescribed for witnesses. Analytically an utterance offered for a purpose which requires the trier to treat the utterer as a witness is hearsay unless the utterer was, when making it, subject to all the conditions imposed upon a witness. ${ }^{2}$ And consistency would seem to require the rejection of such hearsay utterances.

In the field of evidence, however, the evolution of forms of trial, historical accident and considerations of policy often prevent the judicial deci-

2. Professor Strahorn's exposition, supra note I, at $484-486$, seems to call for this conclusion, though he would probably not agree with the course of reasoning by which it is reached. 
sions from reflecting the results of sound analysis and logical consistency. The hearsay rule, as developed by our courts, therefore, may reveal a somewhat different concept from that which our analysis would suggest. Never in the history of our law has all hearsay been rejected. While jurors were in fact "witnesses selected by a public officer," " they were entitled to rely upon information secured "through the words of their fathers and through such words of persons whom they are bound to trust as worthy". 4 And when the parties became privileged to present additional matter through witnesses of their choice, hearsay was freely received. Near the end of the r5oo's serious objection was made, but another century elapsed before it became established that hearsay was ordinarily inadmissible; it was not until well into the I8th century that it was rejected when offered as corroborative evidence. The reason given for its exclusion in the earlier decisions is lack of oath; but in 1668 and 1696 in cases where sworn hearsay was tendered it was rejected for lack of opportunity of the opponent to cross-examine. ${ }^{5}$ During this period the jury was becoming less and less a body of witnesses and more and more a tribunal basing its answers upon evidence submitted in court; the parties were accordingly getting greater and greater control of the course of litigation, and were in effect determining the body of

3. Thayer, Preliminary Treatise on Evidence (1898) 56.

4. This is Dean Wigmore's translation of part of the last sentence of Chapter I 7 of Book II of Glanvind, De Legibus et Consuetudinibus Regni Angliae. In BrunNer, Die ENTStEHUNG DER SCHWURGERICHTE (I872) 427, appears the following: "Die Geschwornen der Assise sind ja berechtigt, auf Grund von Mittheilungen glaubwürdiger Nachbarn auszusagen $^{3}$ ). Sie offenbaren sonach in ihrem Ausspruche eigentlich die in der Gemeinde über die betreffende Beweisfrage herschende Ueberzeugung." The footnote indicated refers back to page 287 , where this sentence occurs: "Nach Glanvilla ist es zur Wissenschaft der Geschwornen erforderlich

quod per proprium visum suum et auditum

illius rei habuerint notitiam vel per verba

patrum suorum et per talia quibus fidem teneantur

habere ut propriis."

The foregoing is given thus in 3 WIGMORE, EvidENCE (2d ed. I923) § I364:

"I872, Professor Heinrich Brumer, The Origin of Jury Courts, 427, 452: ‘. . The jurors of the assize were certainly entitied to give a verdict based on the communications of trustworthy neighbors. Glanvill makes it requisite, for the jurors' knowledge, "that they should have knowledge from their own view and hearing of the matter or through the words of their fathers and through such words of persons whom they are bound to trust as worthy." Thus they exhibit really in their verdict the prevailing conviction of the community upon the matter in question ...?"

Beames, A Translation of Granviri (Ig00) 54, translates the last sentence of Chapter I7 of Book II thus: "With respect to the knowledge requisite on the part of those sworn, they should be acquainted with the merits of the cause, either from what they have personally seen and heard, or from the declarations of their Fathers, and from other sources equally entitled to credit, as if falling within their own immediate knowledge." The text as printed in Woodbine's edition (1932) of GLANVILL, op. cit. supra, at 68, is as follows: "Ad scientiam autem eorum qui super hoc iurant inde habendam, exigitur quod per proprium visum suum et auditum illius rei habeant notitiam, vel per verba patrum suorum, et per talia quibus fidem teneantur habere ut propriis."

Glanvill in the quoted passage is discussing the Grand Assize. No doubt the same statement could have been made of the petty assizes.

5. 2 Roll. Abr. 679, T9 (I668); see Rex v. Paine, 5 Mod. I63, 165 (I696). See generally Morgan, The Jury and the Exchusionary Rules of Evidence (I937) 4 U. OF CHI. L. REv. 247. 
material upon which the jury could act. By the middle of the I70o's this control was almost complete; the jury could no longer act on information acquired by them outside the evidence presented in court, and hearsay was definitely inadmissible.

As our system thus changed from an investigative to an adversary one, the rule rejecting hearsay and that making opportunity for cross-examination a prerequisite to admissibility developed side by side. Was this a mere coincidence? Compare the civil law. That, like the common law, imposes upon witnesses the formalities of the oath and its accompanying sanctions; it sometimes requires confrontation. It has, however, retained the features of an inquisitorial system and has not adopted the adversary theory of litigation. It does not provide for anything like the Anglo-American crossexamination. ${ }^{6}$ And it does not reject hearsay. Is it due to mere historical accident that the inquisitorial system, which has no cross-examination, receives hearsay while the adversary system, which insists on cross-examination, excludes hearsay? It hardly seems reasonable so to conclude. Furthermore, it is generally conceded that of all the conditions imposed upon a witness, quite the most important is that which subjects him to crossexamination. It is, therefore, easy to find support for Mr. Wigmore's dicta that "the Hearsay rule, as accepted in our law, signifies a rule rejecting assertions, offered testimonially, which have not been in some way subjected to the test of Cross-examination" " and it is "that rule which prohibits the use of a person's assertion, as equivalent to testimony to the fact asserted, unless the assertor is brought to testify in court on the stand, where he may be probed and cross-examined as to the grounds of his assertion and of his qualifications to make it." 8

If, however, these statements are to take the place of definitions, they leave much to be desired. They are not identical in meaning or in connotation. The first implies that the assertion will escape condemnation as hearsay if it was in some way subjected to cross-examination. Even if "crossexamination" contemplates an official proceeding before a tribunal empow-

6. 2 Benthais, Rationale of Judictal Evidence (Mill's ed. I827) 433-434: "Among those who in its native country are so cordial in their admiration of this mode of trial [trial by jury], there are not twenty perhaps who at this moment are aware that, in contradistinction to Roman jurisprudence, the mode of extracting the evidence on this occasion is as peculiar to English procedure as the constitution of the court. The peculiarity of the practice called in England cross-examination,- the complete absence of it in every system of procedure grounded on the Roman, with the single exception of the partial and narrow use made of it in the case of confrontation, - is a fact unnoticed till now in any printed book, but which will be as conclusively as concisely ascertained at any time, by the impossibility of finding a word to render it by, in any other language."

3 WIGMORE, op. cit. sitpra note 4 , § I367, n. 2 : ". . . In Continental practice, the examination of witnesses is in theory conducted by or through the judge, by repetition of questions, and in practice cross-examination is so casual or so feeble as to be a negligible quantity. . . "

7. $I d$. at $\S 1362$.

8. $I d$. at $\S 1364$. 
ered to compel cross-examination, the implication is too broad; it is opposed to countless cases. The second statement shifts the emphasis from the assertion to the asserter. He must be brought to testify in court, presumably the court to which the assertion is being offered. There he is to be subject to probing by cross-examination, but the assertion may have been made elsewhere. Here again, any implication that all assertions falling without the confines of this prohibitory rule are non-hearsay runs afoul of numerous authorities. Neither Mr. Wigmore's demonstration of the importance of cross-examination as an engine for the discovery of truth, nor his theory that hearsay is excluded by the Anglo-American law because of lack of opportunity for cross-examination by the opponent, nor yet the effect of the decisions dealing with the admissibility of utterances requires a definition deducible from these statements. Mr. Wigmore's theory may be accepted and harmonized with the results of the suggested analysis by reframing the analytical definition: An utterance offered for a purpose which requires the trier to treat the utterer as a witness is hearsay unless the utterer makes it subject to cross-examination at the trial or hearing at which it is so offered. Practically this would always produce the same result as the strict analytical definition, for wherever the utterer is thus subject to cross-examination, he is also subject to all the other conditions imposed by law upon witnesses.

\section{II}

If a person uses non-verbal conduct instead of words for the purpose of expressing a proposition and if that conduct is offered as evidence of the truth of the proposition, it should be treated exactly as if it consisted of words. For example, if $F$ flees for the purpose of drawing suspicion upon himself, he might as well shout, "I did the act" or "I am guilty." It is quite as necessary that he be under a stimulus to tell the truth as if he had used words to express the proposition. His perception, recollection and veracity need quite as much testing by cross-examination if the trier is to put a fair value upon his conduct. But suppose that $F$ flees only for the purpose of escaping. His flight is everywhere regarded as relevant upon the issue of his guilt. He is not trying to express any proposition, much less the proposition that he is guilty. Neither his veracity nor his narration is in any way involved, once granted that his flight is for the sole purpose of escape. But how is it from the viewpoint of $T$ ? When $P$ offers $F$ ' flight as evidence of $F$ 's guilt, $T$ must first interpret this non-verbal conduct to determine whether $F$ intended to express the proposition that he was guilty. This requires $T$ to ascertain whether $F$ 's conduct honestly reflected his state of mind,-essentially the same thing that is required where $F$ 's conduct is an assertion. If $T$ decides that $F$ was acting solely for the purpose of escaping, then $T$ may 
well infer that $F$ believed himself to be guilty. In order to find that $F^{\prime} s$ state of mind at the time of the flight was caused by his experience of doing the act charged, $T$ must rely upon $F$ 's perception and recollection. $T$ has no opportunity to see $F$ and is entirely without the aid of cross-examination to test the relevant aspects of $F$ 's perception and recollection. And it is a truism that the most efficient device for exposing the worth of testimony is crossexamination and that the most valuable function of cross-examination is its discovery of defects in observation and memory. Consequently in such a case $T$, without the benefit of hearing $F$ cross-examined, is put to relying upon $F$ for the most important functions performed in the usual case by a witness. Where $F$ is not a party to the action, most courts in effect make this analysis, declare $F^{\prime} s$ conduct to be the equivalent of a confession and classify it as hearsay. ${ }^{9}$

Where $F$ 's perception and recollection have to do only with his own voluntary conduct of a striking or unusual character, the dangers of reliance upon his perception and recollection may be negligible; in exceptional instances they may be enormous. Where $F$ 's conduct leads first to an inference concerning his state of mind, and thence to an inference concerning the conduct of a third person or other external matter, $F$ 's perception and recollection are of primary importance. For example if the issue is the life or death of $X$, evidence that $F$ paid to $X^{\prime} s$ beneficiary the full amount of an insurance policy issued by $F$ upon the life of $X$ would require $T$ to rely heavily upon $F$ 's perception and to a varying degree upon his recollection. If $F$ were present and offering to testify that $X$ was dead, and refused to be cross-examined as to his perception and recollection, he would not be heard. Consequently it would not be out of accord with good sense to put $F$ 's nonverbal conduct in the same category as verbal hearsay.

In some instances utterances are offered to prove not the truth of the matter asserted in them but to prove that the utterer believed it to be true and was therefore mentally abnormal. Here his perception and recollection are immaterial; but his narration and sincerity are of the utmost importance. Unless his words, with the meaning ordinarily given to them by him, would reflect an irrational belief and unless he speaks seriously and in good faith, the utterance is no evidence of mental abnormality. When offered as such evidence, the need for cross-examination is clearly indicated, and a classification which puts the utterance within the bounds of hearsay would not be unreasonable.

It is, therefore, suggested that hearsay might be conveniently defined as including ( $\mathrm{I}$ ) all conduct of a person, verbal or non-verbal, intended by him to operate as an assertion when offered either to prove the truth of the matter

9. E. g., State v. Piernot, I67 Iowa 353,149 N. W. 446 (I914), criticised in (1915) 28 HARV. L. REV. 429 . 
asserted or to prove that the asserter believed the matter asserted to be true, and (2) all conduct of a person, verbal or non-verbal, not intended to operate as an assertion, when offered either to prove both his state of mind and the external event or condition which caused him to have that state of mind or to prove that his state of mind was truly reflected by that conduct. This would require a further modification of our analytical definition: any conduct of a person, verbal or non-verbal, offered for a purpose which requires the trier to treat that person as a witness to the extent of relying upon his perception, recollection, narration or veracity is hearsay unless that conduct is subject to cross-examination at the trial or hearing at which it is so offered. ${ }^{10}$

\section{III}

The problem of classifying four groups of assertive utterances has caused controversy: (I) records of past perception, (2) declarations of intent accompanying ambiguous non-verbal conduct of the declarant, the legal significance of which depends upon the accompanying intent, (3) declarations made contemporaneously with a non-verbal act, independently admissible, and explaining, qualifying or throwing light upon it, and (4) admissions. Are these utterances hearsay?

(I) Where a witness convinces the court that he made or verified a memorandum at or about the time of an event which it purports to record and that he then knew that it correctly recorded the event, but that he has now forgotten and is unable to testify about it from present memory, the content of the memorandum is admissible. The hearsay objection is rarely made, and then only when the memorandum is not produced and its content is sought to be proved by oral testimony. The question discussed is the testimonial qualification of the witness and the use of the memorandum as an aid to his recollection. In some courts the witness may read to the jury the content of the paper, but the paper itself is not receivable, ${ }^{11}$ on the theory that the witness is now adopting the content as his present testimony and is permitted to do so because he formerly knew it to be true and now knows it to be true. ${ }^{12}$

Analytically the memorandum is hearsay. The assertions in it were made in the absence of the conditions imposed upon witnesses. To be sure, the asserter is presently subject to all those conditions. He is stimulated to tell what he believes to be the truth about the recorded event but he can speak

Io. See generally McCormick, The Borderland of Hearsay (I930) 39 YALE L. J. 489; Morgan, Hearsay and Non-Hearsay (I935) 48 HARv. L. REv. II38.

II. See Gurley v. Springfield Street Ry., 206 Mass. 534, 537, 92 N. E. 714, 715 (Igro).

I2. Cf. Floyd v. Pugh, 20I Ala. 29, 33, 77 So. 323, 327 (1917), stating that proper verification of the memorandum "legalizes and lets in both the testimony of the witness and the memorandum. The two are declared to be equivalent of a present, positive statement of the witness, affirming the truth of the contents of the memorandum." And see 2 WIGMORE, op. cit. supra note 4 , § 754 . 
only of making or verifying the record. There is no real opportunity to test his perception or his recollection of the event, for he begins by saying that he has no present memory of it. His narration and his desire to tell the truth can be pretty effectively examined; but it must be obvious that in so far as the conditions imposed upon witnesses generally can be applied to him, they are much less likely to produce data which will enable the trier to put a fair valuation upon his testimony than in the case where prior statements, whether consistent or inconsistent, are offered as to an event to which the witness is testifying from present memory. And it is universally agreed that such prior statements are hearsay. Whether the record of past recollection and the prior statements should be treated differently as to admissibility is quite another question. ${ }^{13}$

(2) Declarations in the second group have been said to be non-hearsay, because they are "verbal acts" 14 or are "utterances which are parts of relevant conduct and which come in as conduct and not as narration alone." 15 The validity of this classification may be tested by a familiar case. Suppose that $D$, a resident of Maine, while on a local pleasure trip between Bangor and Portland, says, "I intend to move to Pasadena, California, and to make that place my permanent home thereafter." Here is a declaration of a presently existing state of mind. In all jurisdictions it is classed as hearsay. In some, wherever relevant, it is received as an exception; in others it is rejected. Now assume that $D$ makes exactly the same statement while between Bangor and Portland on a trip to Pasadena. Upon the issue of change of domicile, the journey is a relevant, ambiguous, non-verbal act, and its legal significance depends upon the intent with which $D$ makes it. To evidence that intent the declaration is everywhere admissible. ${ }^{16}$ Is it any the less narrative because it accompanies the non-verbal act? Is it used by the trier in any different way or for any different purpose? There can be but one answer. To classify it as hearsay in the one instance and as non-hearsay in the other is little short of capricious.

(3) The judicial opinions concerning declarations made contemporaneously with an otherwise admissible non-verbal act and tending to throw

I3. Dean Wigmore apparently considers the hearsay rule in no way involved. He treats the matter under Testimonial Recollection. Id. at $\$ 737$ (2). Professor Strahorn treats the content of the memorandum as hearsay but declares it admissible as partially satisfying the hearsay rule. Strahorn, sitpra note I, at 496 et seq. It may be worth noting that he would receive for the truth of the matter asserted in them prior contradictory statements which the witness concedes having made, but not those which have to be proved by others after denial by the witness. He believes this to be the view of Dean Wigmore. It is suggested that he has misread the text: "when admitted" means "when received in evidence", not "when conceded by the witness". Dean Wigmore would hardly have used the word "admitted" in this sense in \$ Ior8, when in \$ ro48, n. 2, he refers to "the well-worn professional jest" in which "admit" is used in the sense of "concede".

I4. See 3 WIGMORE, op. cit. supra note 4 , §§ I772-I786, particularly §§ I782-I785.

I5. See Strahorn, supra note I, at 49 I, n. II.

I6. See Holyoke v. Estate of Holyoke, Iro Me. 469,87 At1. 40 (Igr3). 
light upon it are frequently phrased in the obscure and obscuring language of res gestæ. ${ }^{17}$ Often, too, the non-verbal act is an exciting event which puts the declarant under the stress of a nervous excitement, so that the declaration may be treated as a "spontaneous exclamation". But in some instances the non-verbal act is so casual or routine as to occasion no nervous stress of any kind. Thus, where plaintiff and his engineer were moving a steam engine along a highway by the use of steam-power and horse-power, plaintiff ordered the engineer to shut off the steam; the engineer answered that he had done so. Upon the issue whether the engine was then being propelled by steam, the engineer's statement was offered to show that the steam had been shut off. ${ }^{18}$ Again upon the issue of the speed of a train, a remark by a passenger on "the short period of time consumed in passing" between two designated stations was offered and received. ${ }^{19}$ In these two instances the court was of the opinion that the declarations were admissible as parts of the res gestæ. Such statements the great Thayer and his more famous disciple classify as hearsay. The former believed them admissible because they imported "what was then present or but just gone by, and so was open, either immediately or in the indications of it, to the observation of the witness who testifies to the declaration, and who can be cross-examined as to these indications. . . ." 20. The latter considers them inadmissible except where the non-verbal act or event puts the speaker under the stress of a nervous excitement which makes his declaration spontaneous. And the majority of the courts agree with Mr. Wigmore. Analytically these declarations are hearsay; the declarant is performing all the functions of a witness and is subject to none of the conditions imposed upon witnesses. If this is true, what difference can it make that the testimony accompanies an act or event which is independently admissible? As to admissibility it may be all important; as to its hearsay or non-hearsay quality, it is altogether immaterial. It helps not at all to assert that the words are non-narrative, for they fall squarely within the dictionary definition of narration. They may by a little stretch of the imagination be said not to be narrative of a past event; but narrative of a contemporaneous event they certainly are, and they are offered for the truth of the matter narrated, and for no other purpose.

I7. When counsel was attempting to introduce certain hearsay, Holmes, J., presiding, said: "No, the hearsay rule has been a good deal nibbled round the edges, but nobody has taken quite such a bite out of it as that. And I think I won't set the example." "Not as part of the res gestae?" asked counsel. Holmes, J., replied: "The man who uses that phrase has lost temporarily all power of analyzing ideas. For my part, I prefer to give articulate reasons for my decisions." Ex relatione Samuel Williston as recorded in an unpublished journal of James Bradley Thayer (1895).

I8. Stebbins v. Keene Twp., 55 Mich. 552, 22 N. W. 37 (1885).

I9. Missouri Pacific Ry. v. Collier, 62 Tex. 318 (I884).

20. THAYER, Bedingfield's Case-Declarations as a Part of the Res Gesta in LEGAI Essays (1908) 207,302, also to be found in (188I) 15 AM. L. REv. 7I, I07. See Morgan, A Suggested Classification of Utterances Admissible as Res Gestae (1922) $3 \mathrm{I}$ Y YLE L. J. 229,
236. 
(4) Three theories have been advanced in support of the proposition that admissions do not constitute hearsay. Greenleaf, apparently relying upon what he believed to be the opinion of Mascardus, considered them "as a substitute for the ordinary and legal proof; either in virtue of the direct consent and waiver of the party, as in the case of explicit and solemn admissions, or on grounds of public policy and convenience, as in the case of those implied from assumed character, acquiescence or conduct." 21 Wharton, expressing the same idea, said, "an admission is a fact to be proved by evidence, not evidence to prove a fact." 22 These writers seemed to put extrajudicial admissions in the same class as judicial admissions. They find no followers in either modern judges or modern commentators. The second view treats an admission not as evidence of the matter asserted in it but merely as impeaching the position taken by a party in his pleadings and at the trial in the same way that a prior contradictory statement is used to impeach a witness. This seems to be advocated by Mr. Wigmore in the sixteenth edition of Greenleaf and in the first edition of his own masterpiece. ${ }^{23}$ If so, it is abandoned in the second edition and is not accepted by the courts. The third theory, that admissions constitute not testimonial but circumstantial evidence of the truth of their content has been suggested by $\mathrm{Mr}$. Wigmore, ${ }^{24}$ and has recently been restated and elaborated by Professor Strahorn. He says that they "are usable because they are the relevant conduct of a party or of one having a relevant relation to a party, and that therefore they can be rationalized without reference to their trustworthiness even if they might possess narrative value also." 25

Just what does this mean? How is this conduct relevant? In much the same way that a prior inconsistent statement of a witness is relevant. The "unfavorable verbal conduct of a party litigant may be offered against him because of the circumstance of its inconsistency with the validity of his present contention by pleading. The circumstance of the party's statement being at variance with his present contention by pleading is such a cogent one that it may be considered by a jury, even to the extent of giving it the same weight as if the facts apparently narrated in it (if it does also happen to have narrative content) were true." 26 This calls for critical examination.

Suppose the issue to be whether $D$, a party to the action, or $B$, a third person, committed act $\mathrm{X}$. $W$ offers to testify that he heard $B$ say: "I com-

21. I Greenteaf, Evidence (Ist ed. I842) $§ 169$. This was repeated in the succeeding fourteen editions.

22. 2 Wharton, Evidence (Ist ed. 1877) § I075. See also Hamersley, J., in State v. Willis, 7I Conn. 293, 308, 41 Atl. 820, 824 (I898).

23. I GReEnLEAF, EVIDENCE (I6th ed. ISg9) § I69; 2 Wrgmore, Evidence (Ist ed. 1904) $\S$ ro48. See also Note (I920) 34 HARv. L. REV. 205.

24. I WIGMORE, op. cit, supra note $23, \S 267$.

25. Strahorn, supra note $I$, at 570.

26. Id. at 573. 
mitted act X." No one doubts that B's utterance, if made, is relevant verbal conduct of $B$. But how relevant? As the basis for inferences by $T$ that $B$ intended to convey the idea ordinarily expressed by these words, that he believed what he said, and that his belief was caused by his commission of act $\mathrm{X}$. If $B$ makes his statement directly to $T$, it is direct, as distinguished from circumstantial, evidence as those terms are ordinarily used. If $B$ 's statement is transmitted to $T$ by $W$, it is, of itself, none the less direct. It is universally classed as hearsay.

Assume further that $B$ has already testified at the pending trial: " $I$ did not commit act X." In what way does this affect the relevancy of $W$ 's, testimony? Upon the issue of $B^{\prime} s$ commission of the act, $T$ must still answer the questions: (I) Did $B$ use the words reported by $W$ ? (2) If so, did he intend to express the idea usually conveyed by those words? (3) If yes, did he believe them to be true? (4) If he did, what caused him to have that belief? In seeking answers, $T$ will be aided by $B$ 's testimony, and by the fact of its inconsistency with his former statement. If the answers to the first two are in the affirmative, they will also help $T$ to set a value upon $B$ 's testimony. The result may be that $T$ will conclude that it is impossible to determine whether $B$ was telling the truth on either occasion, or that his former story was true and his testimony mistaken or deliberately false. The courts, however, will permit $T$ to go no farther than to find that $B^{\prime} s$ testimony is worthless. They will not allow a finding of the truth of $B$ ' $s$ former statement. Why? Because it is hearsay, and the inconsistency between it and $B$ 's testimony alters this characteristic not one whit.

If the statement and testimony are by $D$ instead of $B$, in what respect can the analysis be different? The questions that $T$ will have to answer and the processes for reaching results will be identical. Even though $D$ does not testify, the position which he is taking in his pleadings and at the trial is said to be the equivalent of testimony by him that he did not commit act X. It is quite as inconsistent with his former statement; but it cannot in the slightest degree change the questions which $T$ must put concerning $W^{\prime} s$ testimony or the processes by which $T$ reaches his result. $T$ must treat $D$, when making the former statement, as a witness, and must subject $D$ 's assertion to exactly the same processes as any other assertion received in evidence. If the former statement is hearsay when made by $B$, it is equally hearsay when made by $D$. Doubtless it tends to impeach the speaker, be he $B$ or $D$, by its inconsistency with the position he takes at the trial in his testimony or otherwise. When offered for its truth, it is rejected as hearsay if made by $B$; if made by $D$, it is received notwithstanding its hearsay character, and regardless of the circumstances under which it was uttered. ${ }^{27}$ They may or

27. This statement is too broad if applied to that species of admissions which are usually classed as confessions. The circumstances under which a confession was uttered may cause its exclusion. 
may not have furnished a guaranty of its trustworthiness or an indicium of its intrinsic superiority. Its admissibility depends upon quite different considerations. ${ }^{28}$

\section{IV}

Admissions, dying declarations, pedigree statements and certain entries in books and documents have always been received by the Anglo-American courts. ${ }^{29}$ Why did they escape condemnation when the hearsay rule took form? Why have various utterances of persons speaking other than as witnesses in open court been admitted in evidence? Is it possible so to classify the decisions as to make this branch of the law appear consistent and sensible? Does Mr. Wigmore give satisfactory answers? Beginning with Mr. Thayer's postulate that the Anglo-American law of evidence is the child of the jury, he attributes the exclusion of hearsay to the court's determination to prevent the jurors from being misled by unreliable testimony. That admissions are not hearsay was the position he took in his first edition. There he seemed to say that they were not received for the truth of the matter asserted in them. To what extent he has departed from that view may be subject to debate. That they may be used as substantive evidence, rather than for impeaching purposes only, he now concedes; but since in his second edition he still continues to treat them under the sub-title Testimonial Impeachment, it may well be that he considers them as circumstantial rather than direct evidence of the matters stated in them. Reported testimony, he - believes, satisfies the hearsay rule. Other admissible hearsay utterances are exceptions to the rule. For each of them he finds some guaranty of trustworthiness and some necessity for its use. To be sure, the guaranty is often pretty slender, and the necessity may on occasion amount to no more than

28. If the exposition in the text is valid as to express admissions, it has at least equal validity when applied to vicarious admissions. Whether admissions by conduct not intended to express a proposition shall be classed as hearsay depends upon the acceptance or rejection of the theory set forth in the second division of this article.

Nowhere in his article does Professor Strahorn explain how a jury can or will use any narrative admission in any manner different from that in which it uses any other narrative statement. He seems to assume that what he terms the process of double inference will furnish a theoretical basis for the use of utterances of a party or of one in "a relevant relation to a party" different from that upon which the use of utterances of others is founded. Strictly speaking, the first inference from the conduct of a person is to his state of mind as the cause of the conduct, and the next from his state of mind to the condition or event causing that state of mind. Thus the inconsistency between $D$ 's prior statement and his position at the trial is the basis for an inference to $D$ 's state of mind, and when that is determined, it may be the foundation for a further inference to the external events in issue. It may be argued more loosely that $D$ 's former statement is used only to prove its inconsistency with his present position, that the inconsistency justifies the inference that that position is false, and that this falsity warrants the inference that the opposite of that position is true; which just happens to coincide with the truth of the prior statement. But it is well settled that a finding by the trier that a party is testifying falsely cannot serve as the basis for a further finding that the opposite of the testimony is true. See Hyslop v. Boston \& Me. R. R., 208 Mass. 362, 94 N. E. 3Io (rgII), 21 ANN. CAS. II23; Moulton v. Moulton, I78 Minn. 568, 227 N. W. 896 (r929); People v. Rides, 273 N. Y. 214, 7 N. E. (2d) ro5 (1937).

29. See Thayer, op. cit. supra note 3 , at 519-521. 
convenience. From the viewpoint of the declarant, the guaranty may consist only of circumstances which would induce an ordinary man in his place to desire to tell the truth or at least would offer him no inducement to falsify. ${ }^{30}$ And it is the subjective condition of the declarant which appears to Mr. Wigmore to be of primary importance. With all this Professor Strahorn agrees, except that he finds in most of the exceptions nothing which will stimulate the declarant to truth-telling but much that would make likely the accuracy of his observation and recollection and perhaps of his narration. Professor Strahorn prefers to speak in terms of intrinsic superiority rather than of guaranties of trustworthiness. ${ }^{31}$

This classification makes the subject-matter appeat to have a unity and rationality which it totally lacks. The hearsay rule, with its qualifications and exceptions, cannot be explained solely as a device for protecting an unskilled body of triers from misleading testimony. It is due quite as much, if not more, to the adversary system of litigation. The rules governing the reception of admissions find their explanation in the adversary theory of litigation. ${ }^{32}$ If the jury is to be protected from testimony of a misleading character, how can it be allowed to hear an extra-judicial statement of a party to the action which was made under a positive stimulus to falsify, in the form of an opinion, and based not on personal knowledge but upon self-

30. Dean Wigmore may not be willing to vouch for all statements in the report of the Commonwealth Fund Committee of which he was a member. In that report is the following deduction concerning cases in which hearsay is received: "A study of the precedents leads irresistibly to the conclusion that in these classes of cases the courts have in the main required merely that the declarant have knowledge of the facts and be so situated that the ordinary man under the same circumstances would normally speak the truth." MORGAN ET AL., Tre Law of Evidence: Some Proposals For Its Reform (I927) 38. The chairman of that committee is still of opinion that the conclusion is accurate in so far as the court looks to the subjective condition of the deciarant.

3r. Strahorn, supra note I, at 500-509, 564-568. As will appear from various parts of the text, the test of admissibility of a hearsay statement should, in the opinion of the writer, be the capacity of the jury to put a fair value upon it. The subjective condition of the declarant and the objective circumstances under which the declaration was made, as well as the character of the usual content of such a declaration, are factors which aid the court in determining whether the proffered declaration belongs to a class of utterances which the jury may be safely trusted to value with approximate accuracy. Whether the result be phrased in terms of guaranty of trustworthiness or intrinsic superiority or capability of valuation is not of great importance. The capacity of a jury to handle hearsay in a case in which competent counsel and a competent trial judge are engaged has been greatly underestimated; and the Massachusetts Hearsay Statute, MASS. GEN. LAws (1932) c. 233 , 65 , goes a long way toward removing much foolishness exhibited in the decisions.

32. This is true of vicarious admissions as well as of personal admissions. Statements authorized by the adversary to be made should, of course, be treated as if he had made them. Statements made by persons who stand in certain substantive relations to the adversary are also considered as if he had made them. This may be due to the historical accident that early judges confused substantive liabilities with evidence probative of them. As has been shown elsewhere, most of the utterances admitted on this theory have been obviously and consciously against the interest of the utterer. Only a very few cases can be found in which a selfserving statement was so received. Consequently the result of all but a small number of decisions can be rationalized on another ground-a ground that appeals to reason. Whatever unreason there is in this branch of the law cannot be explained away by calling an utterance merely circumstantial evidence of the truth of the matter asserted in it, especially since the courts receive it for its truth, the jury considers it like any other assertion, and in most instances it has no significance in favor of the proponent unless it is true. 
serving hearsay? ${ }^{33}$ The decisions rejecting former testimony given in a judicial proceeding subject to cross-examination upon the same issue by the very party against whom it is now offered, because the proponent was not a party to the former proceeding, can be justified on no rational ground but can be partially explained by the notion that one adversary should not be permitted to use a weapon denied to the other. The orthodox doctrine, which confines the reception of dying declarations to those of the victim for whose homicide the defendant is now being prosecuted, squares neither with the adversary theory nor with the notion of protecting the jury. It rests upon the conviction that such evidence is needed in homicide cases and that hearsay is better than no evidence. It is true that in many categories of admissible hearsay the utterance was made under circumstances which the courts believe make it capable of reasonable evaluation by ordinary jurors. Whether these circumstances are described as constituting a guaranty of trustworthiness or as giving the utterance "intrinsic superiority" is of little moment. What is important is that the reasoning upon which the decisions in these categories is based is at war with that upon which decisions in some other categories are founded; and is fundamentally opposed to assumptions in other closely related portions of the field of evidence.

An illustration will disclose what a conglomeration of inconsistencies might occur in litigation growing out of a single accident. In a collision between an automobile driven by $X$, in which $A$ and $B$ were riding, and an automobile driven by $S$, the servant of $D, X$ and $A$ were severely injured. $A$ died within a few days, after making a dying declaration describing the conduct of $X$ and $S$ just before and at the moment of the collision. $X$ and $A$ 's administrator brought separate actions against $D . S$ was indicted for the manslaughter of $A$. The action of $X v . D$ was brought on for trial; $X$ testified at length and was subjected to a searching cross-examination by $D$. Before $D$ 's testimony was concluded, a mistrial was declared. $X$ died, and his administrator was substituted as plaintiff. For the trials of $X$ 's Administrator v. $D$, A's Administrator $v$. $D$, and State $v$. S, the following items of relevant evidence are available: (I) X's testimony at the trial of $X v . D$; (2) the dying declaration of $A$; (3) a written statement made by $D$ ten days after the accident to the effect that $S$ was driving at an excessive rate of speed and was therefore unable to stop at the intersection at which the collision occurred. It is conceded that at the time of the accident, $D$ was more than 1000 miles distant. (4) An oral statement of $X$ made to $W$ that he was driving fast and didn't notice that he was approaching the intersection at which the collision occurred; (5) An affidavit by $B$ that an instant before

33. This would be the effect of combining the following cases: Atchison, T. \& S. F. Ry. v. Potter, 60 Kan. 808, 58 Pac. 47I (I899) ; Cady v. Doxtator, I93 Mich. I70, I59 N. W. I5I (IgI6); Mayhew v. Travelers' Protective Ass'n, 52 S. W. (2d) 29 (Mo. App. 1932); Reed v. McCord, I60 N. Y. 330, 54 N. E. 737 (I899). 
the collision occurred $X$ was looking back over his shoulder and talking to $A$ who was in the back seat.

Item (I) is admissible in the trial of $X$ 's Administrator $v . D$ if the applicable wrongful death statute is a so-called survival act; it is inadmissible if the statute is like Lord Campbell's act; if the statute contains a combination of these two acts, then item ( $I$ ) is admissible in so far as plaintiff is trying to recover for damages suffered by $X$ before his death, but inadmissible in so far as plaintiff is seeking damages for pecuniary loss caused to the survivors by $X^{\prime} s$ death. ${ }^{34}$ At the trial of $A$ 's Administrator $v . D$ and of State v. $S$, it is unqualifiedly inadmissible. Obviously item (I) is quite as trustworthy, has quite as much intrinsic superiority, is quite as capable of reasonably accurate valuation by the jury in one trial as in either of the others, and that without regard to the provisions of the wrongful death act. Only the sporting theory of the adversary system and the mysterious qualities of legal privity can account for these decisions of the orthodox courts.

Item (2) is inadmissible in each of the civil cases, but is admissible in the criminal prosecution of $S$. If the indictment were for the manslaughter of $X$, or for driving so as to endanger life, or for any offense except the homicide of $A$, it would be inadmissible. Here again there can be no distinction between the trials based upon the character or value of the evidence. The adversary theory would call for its rejection in all cases, the trustworthiness theory for its reception. Only the so-called policy of necessity for using the evidence in homicide cases can explain its reception in the criminal case and its rejection in the others.

Item (3) is admissible against $D$ in both the civil actions, but is excluded in the criminal prosecution. It is clear that if $D$ were called as a witness, he could not testify to these matters because of lack of first-hand knowledge. The evidence would be regarded as practically worthless. Obviously it can be worth no more in the civil cases than in the prosecution of $A$. Its reception in them offends every tenet of the trustworthiness test and is explained only by the adversary theory.

Item (4) if offered by $D$ in the case of $X^{\prime} s$ Administrator $v . D$ would receive the same treatment as item (I), and for the same reason. It would be excluded in the other civil case and in the criminal prosecution.

Item (5) would be inadmissible in all three cases. It would be clearly relevant in the action of $X$ 's Administrator $v$. $D$, and it might be so in the other two cases; but it is plainly hearsay and falls within no exception. If, however, $B$ had been called as a witness and had given testimony contrary to the affidavit and had had his attention called to the affidavit, it would have been received in evidence. It is, however, so lacking in intrinsic worth or trustworthiness that the jury cannot be allowed to use it for its truth because

34. See Eldridge v. Barton, 232 Mass. I83, I22 N. E. 272 (I919). 
it may mislead them. Consequently they must be told that they cannot consider it as evidence of $X$ 's conduct; they can treat it only as an attack upon the credibility of $B$ as a witness; it may help them to determine whether to believe B's testimony but it cannot help them in determining $X$ 's conduct.

It, therefore, seems not only futile but positively harmful to make a classification of utterances which appears to give to the decisions an element of coherent reasonableness which they lack. It is much better to class as exceptions to the hearsay rule all groups of admissible utterances which are offered for a purpose which requires the trier to treat the utterer as a witness and which are made without being subject to cross-examination at the trial in which they are so offered. This will require an exposition of the reasons upon which each exception stands; it will stimulate comparison of one with the other; it will expose the rulings for what they are, a hodgepodge of inconsistencies due to the application of conflicting theories and historical accidents. It will show what a shadow the original rule has become and may persuade the courts to treat in sensible fashion non-verbal conduct which they analyze as the equivalent of verbal hearsay. It will reveal the hopelessness of bringing order out of chaos by the slow process of judicial decision and demonstrate the necessity for intelligent legislative action. 